\title{
Histopathologic evaluation of the peritoneum exposed to heat shock. Experimental study in rats ${ }^{1}$
}

\author{
Avaliação histopatológica do peritônio exposto a choque térmico. Estudo \\ experimental em ratos
}

\author{
João Vieira Lopes², Paulo Gonçalves de Oliveira ${ }^{3}$, João Batista de Sousa ${ }^{3}$, Sonia Nair Báo ${ }^{4}$, Gustavo Henrique \\ Soares Takano ${ }^{5}$, Isabel Irene Rama Leal ${ }^{5}$ \\ 1. Research performed at Experimental Surgery Laboratory, Medical School, University of Brasília (UnB), Distrito Federal, Brazil. \\ 2. Master, Affiliate Professor, Medical School, UnB, Distrito Federal, Brazil. \\ 3. Associate Professor, Medical School, UnB, Distrito Federal, Brazil. \\ 4. Associate Professor, Department of Cellular Biology, Biological Science Institute, UnB, Distrito Federal, Brazil. \\ 5. MD, Pathologist, Pathologic Anatomy Center, UnB, Distrito Federal, Brazil.
}

\begin{abstract}
Purpose: To evaluate histopathologic alterations of the peritoneum exposed to heat shock. Methods: Sixty rats were randomly distributed into 6 groups: Heat Shock (HS), High Temperature (HT), Body Temperature (BT), Temperature 0oC (TZ), Sham (SH) and Control (CG) with 10 animals each. The peritoneal cavity of animals from groups HS, HT, BT and TZ was irrigated with $\mathrm{NaCl}$ solution $0.9 \%$ at temperatures $50^{\circ} \mathrm{C}, 0^{\circ} \mathrm{C}, 50^{\circ} \mathrm{C}, 37^{\circ} \mathrm{C}$ and $0^{\circ} \mathrm{C}$, respectively. For animals from group $\mathrm{SH}$, the procedures were simulated and those from group CG, laparotomy and biopsies were conducted. Twenty-four hours later, biopsies of the peritoneum for exams under light and electronic microscopy were performed. Results: Edema was found in groups HS 80\%, HT 60\%, BT 30\% TZ 70\%, SH 40\% and CG 30\%. Vascular congestion was found in groups HS 20\%, HT 30\%, BT 10\% and TZ 20\%. Erythrocyte extravasation was found in groups HT 60\% and SH 10\%. Mesothelium destruction was found in 100\% of specimens from groups HS, HT, BT, TZ, SH and CG 90\%. Necrosis was found in groups HS 30\%, HT 20\% and BT 10\%. The mean peritoneal thickness ranged from $42.26 \mu \mathrm{m}$ (TZ) to $26.42 \mu \mathrm{m}$ (CG). Conclusion: The heat shock caused no deaths, but promoted significant peritoneal edema without affecting the other histopathologic indicatives. Key words: Heat-Shock Response. Peritoneal Lavage. Peritonitis. Rats.
\end{abstract}

\section{RESUMO}

Objetivo: Avaliar alterações histopatológicas do peritônio exposto a choque térmico. Métodos: Sessenta ratos foram distribuídos aleatoriamente em seis grupos: Choque Térmico (CT), Temperatura Elevada (TE), Temperatura $0^{\circ} \mathrm{C}$ (TZ) Sham (SH) e Controle (GC) com 10 animais. A cavidade peritoneal dos animais dos grupos CT, TE, TC e TZ foi irrigada com solução de $\mathrm{NaCl} 0,9 \%$ nas temperaturas, $50^{\circ} \mathrm{C}$ e $0^{\circ} \mathrm{C}, 50^{\circ} \mathrm{C}, 37^{\circ} \mathrm{C}$ e $0^{\circ} \mathrm{C}$, respectivamente. Nos animais do grupo $\mathrm{SH}$ foram simulados os procedimentos e nos do GC laparotomia e biópsias. Depois de 24 horas foram realizadas biópsias do peritônio para exames sob microscopia de luz e eletrônica. Resultados: Edema foi encontrado nos grupos CT 80\%, TE 60\%, TC 30\%, TZ 70\%, SH 40\% e GC 30\%. Congestão vascular foi encontrada nos grupos CT 20\%, TE 30\%, TC 10\% e TZ $20 \%$. Extravasamento de hemácias foi encontrado nos grupos TE 60\% e SH 10\%. Destruição de mesotélio foi encontrada em 100\% dos espécimes dos grupos CT, TE, TC, TZ, SH e no grupo GC 90\%. Necrose foi encontrada nos grupos CT 30\%, TE

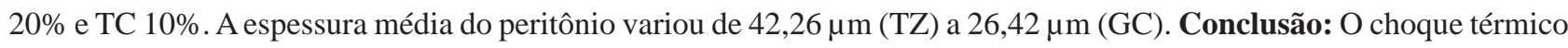
não causou óbitos, mas promoveu edema peritoneal significante sem alterar os demais indicadores histopatológicos. Descritores: Resposta a Choque Térmico. Lavagem Peritoneal. Peritonite. Rats. 


\section{Introduction}

Heat shock may be stimulated in the peritoneal cavity (PC) through irrigation with $\mathrm{NaCl}$ solution $0.9 \%$ (saline) at different temperatures employed in peritoneal lavage (PL). PL is used by abdominal surgeons since 1905 when Price1 proposed its use to remove purulent secretions and other impurities from the PC with peritonitis ${ }^{2,6,10}$. Although the incorporation of new surgical techniques, the better comprehension about the disease pathophysiology, the use of antibiotics and employment of intensive care in prevention and treatment of the diffuse peritonitis have contributed for the reduction on the mortality rate, this disease is still a fearful complication and its mortality rate has decreased only from $40 \%$ to $30 \%$ in the last 30 years $^{3}$. In the localized form of the secondary peritonitis, the mortality rate ranges from $1 \%$ to $3 \%$ while in the diffuse peritonitis, it ranges from $30 \%$ to $85 \%{ }^{4,16}$. On the other hand, tertiary peritonitis associated infection due to Candida albican may present mortality rate of up to $75 \%{ }^{5}$. The PL was initially discussed as routine procedure for the reduction of the contamination level in peritonitis by authors who supported the PC irrigation as contamination propagation factor $^{6}$. Maingot ${ }^{7}$ is among these authors and proposed: "In my opinion, irrigation of the peritoneal cavity with cleanness purposes is never justified even in the presence of gross fecal contamination”. However, although the concept of contamination propagation remains, it has not been clinically verified ${ }^{6}$ and cannot not applied to diffuse peritonitis when the contamination already involved the entire peritoneum. The parietal peritoneum consists of a single layer of mesothelial cells and a conjunctive tissue layer containing cells, blood vessels, lymphatic vessels and nervous fibers ${ }^{8,9}$, what may be physically and biologically similar to the dermis that once injured and contaminated, needs the purulent secretion, strange bodies, dead tissues and other impurities to be washed off ${ }^{3}$. Once recognized that PL was vital for the treatment of the secondary peritonitis ${ }^{3,4,6,23}$, researchers added to the saline solution substances such as antibiotics ${ }^{2,11,24}$, antimicrobial agents ${ }^{12}$, chemotherapic agents ${ }^{13}$, hypertonic glucose $10 \%{ }^{14}$ and immunoglobulin ${ }^{15}$ with the objective of increasing the procedure efficiency. Although there are clinical and experimental researches on PL with saline solution associated or not to different substances, references on histopathologic alterations that the temperature of these solutions could cause in the peritoneum are scarce ${ }^{16-18}$. In practice, the temperature of the saline solution used in the PL does not receive adequate attention ${ }^{19}$ and is commonly referred as "lukewarm serum", according to the surgeon's tactile sensitivity. However, the temperature and/or its sudden variation, the heat shock, may cause stress and cell death ${ }^{16-19}$,, and produce protective effects in the sepsis with protein expression of the heat shock ${ }^{20}$, in malignant neoplasia ${ }^{21}$ and in the food deterioration prevention ${ }^{22,25}$. In 1864, Pasteur apud Debré22 studied the wine manufacturing process and observed that deterioration occurred due to the action of microorganisms present in the medium and later found that heating at controlled temperature conditions from $55^{\circ} \mathrm{C}$ to $60^{\circ} \mathrm{C}$ eliminated microorganisms without affecting the wine organoleptic properties, which remained salutary if kept cooled in closed recipient with no contact with oxygen ${ }^{22}$. This partial sterilization process with temperature raise at controlled conditions followed by cooling widely used for food conservation was called as pasteurization $^{22}$. The employment of saline solution for PL at high temperature followed by lavage with solutions at low temperature, the heat shock, could also produce damages to microorganisms found in the peritoneum, similarly to the milk pasteurization process ${ }^{22}$, but it could also cause histopathologic alterations in the peritoneum, muscles or in the intestine wall as those observed in response to the exposition of these tissues to biological agents ${ }^{9}$. In this context, in an experimental research, Silva, et al. ${ }^{19}$ reported that when the saline solution at temperature of $60^{\circ} \mathrm{C}$ used for PL in rats remained within the PC for 1 min could cause histopathologic alterations in the peritoneum and in the muscular fibers of the PC posterior wall perceived at light microscopy with mortality rate of $66 \%$ at the first 24 hours. However, the solution caused no histopathologic alteration when used at temperature of $45^{\circ} \mathrm{C}$ during equal period of time. In 1991, the employment of peritoneal irrigation with saline solution at different temperatures for the peritonitis treatment in human beings with encouraging results was reported. The process described as heat shock consists of the irrigation of the peritoneal cavity with saline solution at temperature between $48^{\circ} \mathrm{C}$ and $50^{\circ} \mathrm{C}$ during 20 minutes shortly followed by peritoneal lavage with other solution at temperature between $0^{\circ} \mathrm{C}$ and $2^{\circ} \mathrm{C}$ during 5 to 10 $\min ^{17}$. The objective of the present study was to evaluate possible histopathologic alterations in the peritoneum of rats exposed to heat shock due to $\mathrm{PL}$ with saline solution at temperature of $50^{\circ} \mathrm{C}$ shortly followed by another PL with saline solution at temperature between $0^{\circ} \mathrm{C}$ and $2^{\circ} \mathrm{C}$.

\section{Methods}

The experimental procedures were conducted according to ethic principles of the Brazilian Bureau of Animal Experimentation (COBEA) and were approved by the Ethics Committee for Animal Use (CEUA) from the Biological Sciences Institute (ICB) - University of Brasilia. Sixty healthy male Wistar rats (Rattus norvergicus) weighting between 340 and 400 g, from 100 to 120 days old were distributed by simple allotment with no reposition into 6 groups, namely: Group 1, heat Shock (HS); Group 2, High Temperature (HT); Group 3, Body Temperature (BT); Group 4, Temperature $0^{\circ} \mathrm{C}$ (TZ); Group 5, Sham (SH) and Group 6, Control (CG). The animals were anesthetized with intramuscular cetamine chloridrate at dose of $90 \mathrm{mg} /$ $\mathrm{kg}$ associated to xylazin at dose of $5 \mathrm{mg} / \mathrm{kg}$ and submitted to median laparotomy of $4 \mathrm{~cm}$ with the caudal extreme of 
the incision $2.0 \mathrm{~cm}$ from the external genitalia.

\section{Experimental protocol}

The PC was exposed with the aid of an aluminum frame (Figure 1, A and B), filled and emptied with saline solution according to protocol established for each group of animals, except for those from the control group, which were submitted to laparotomy and biopsies and those from the Sham group, which were submitted to experimental simulation (Table 1). Twenty-four hours after laparotomy,

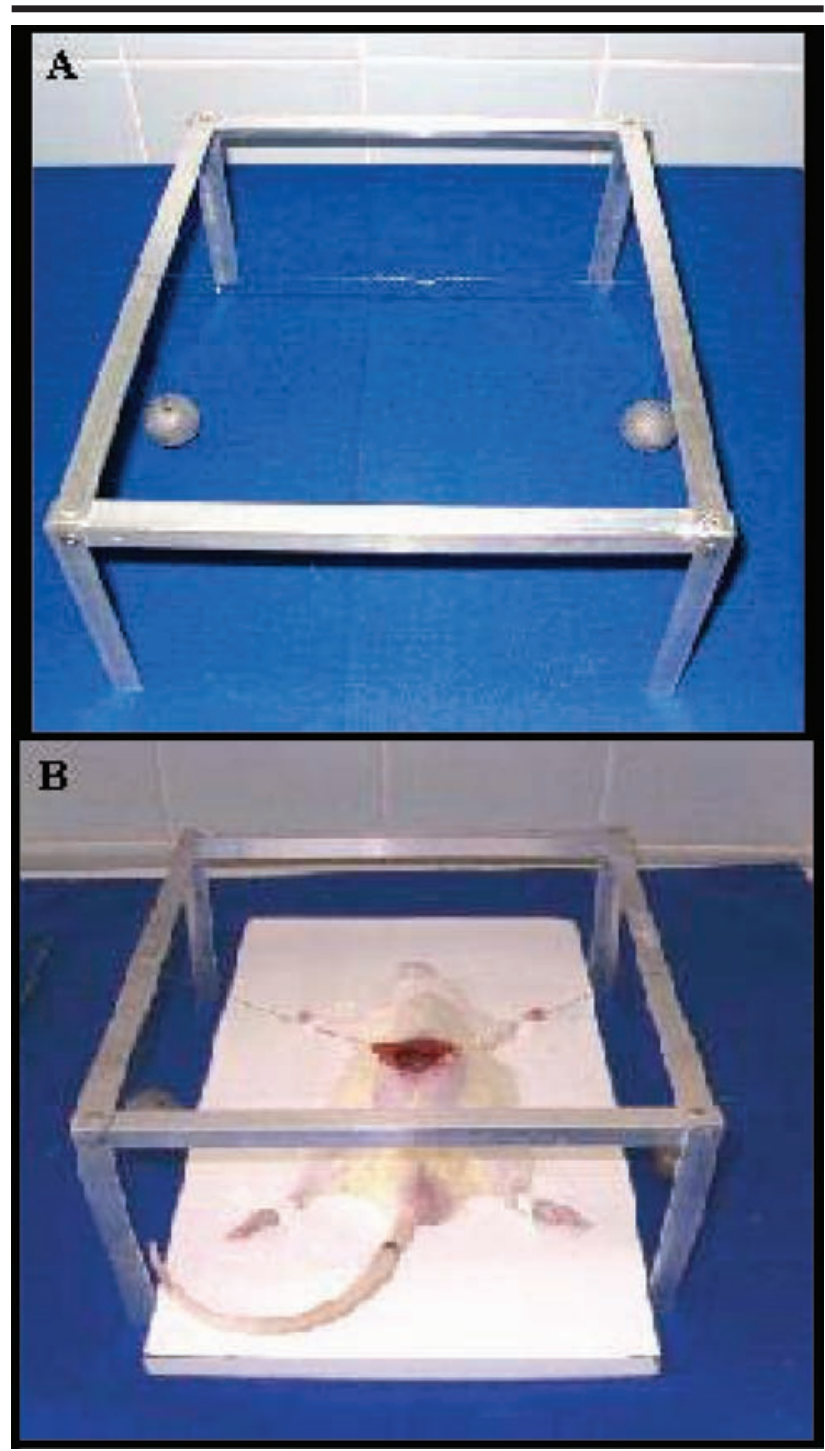

FIGURE 1 - Aluminum frame used for the PC exposition of small animals submitted to specific experiments and lead balls fixed to nylon wires and hooks (A) applied to the rim of the surgical wound that when supported on the aluminum frame, pull and expose the PC (B) all animals were anesthetized and re-operated for the performance of biopsies, except for animals from the control group that had already been submitted to biopsies at the first procedure. During re-operation, samples from the anterolateral wall of the left side of the peritoneal cavity were collected for histopathologic examination under light microscopy (LM) and in the fifth animal from each group, biopsy using the biopsy punch technique of the right side was also performed for analysis under transmission electronic microscopy (TEM). After these procedures, the animals received intracardiac lethal dose of sodium thiopental $2.5 \%$.

TABLE 1 - Description of the surgical procedures performed in animals from groups HS, $\mathrm{HT}, \mathrm{TZ}, \mathrm{BT}, \mathrm{SH}$ and CG according to experimental protocol

\begin{tabular}{|c|c|}
\hline Groups & Surgical procedures \\
\hline HS & $\begin{array}{l}\text { The } \mathrm{PC} \text { was filled with saline solution at } 50^{\circ} \mathrm{C} \\
\text { and kept filled up during } 1 \text { min. After this } \\
\text { period, it was emptied and shortly filled up } \\
\text { with saline solution at temperature between } \\
2^{\circ} \mathrm{C} \text { and } 0^{\circ} \mathrm{C} \text { and emptied } 1 \text { min later. }\end{array}$ \\
\hline HT & $\begin{array}{l}\text { The PC was filled with saline solution at } \\
50^{\circ} \mathrm{C} \text { and kept filled up during } 1 \text { min. After } \\
\text { this period, it was emptied and the filling } \\
\text { was simulated and } 1 \text { min later, the emptying } \\
\text { simulation was conducted. }\end{array}$ \\
\hline
\end{tabular}

CT The PC was filled with saline solution at $37^{\circ} \mathrm{C}$ and kept filled up during $1 \mathrm{~min}$. After this period, it was emptied and shortly filled with saline solution at the same temperature and emptied 1 min later.

TZ The PC filling was simulated and 1 min later, the emptying simulation was conducted. Following, the PC was filled with saline solution at temperature between $0^{\circ} \mathrm{C}$ and $2^{\circ} \mathrm{C}$ and kept filled up during $1 \mathrm{~min}$. The $\mathrm{PC}$ was emptied after this period.

$\mathrm{SH} \quad$ The PC filling was simulated and 1 min later, the emptying simulation was conducted. After this period, a new filling simulation was shortly conducted and 1 min later, the emptying was simulated.

CG Laparotomy and collection of samples from the anterolateral wall of the left side of the peritoneal cavity for histopathologic examination and morphometry. In the fifth animal from this group, biopsy of the right side was also performed for analysis under transmission electronic microscopy. 


\section{Light Microscopy (LM)}

Samples of $10 \times 5 \mathrm{~mm}$ composed of peritoneum and a muscular layer of the PC anterolateral wall were fixed in formaldehyde $10 \%$, dehydrated in ethanol, paraffin included, cut in microtome Leica RM2125RT into sections of $6 \mu \mathrm{m}$ thickness, assembled in microscope slides and stained with hematoxilin/eosin (HE). The examination of the microscope slides was performed using microscope Zeiss oxicop 2 with lens of $40 \mathrm{X}$ and ocular of 10x23 mm to investigate the presence of edema, vascular congestion, erythrocyte extravasation, mesothelium destruction and focal necrosis classified from 1 to 4 , corresponding to the following levels: 1 - absent; 2 - slight; 3 - moderate and 4 - intense. Five different fields from each slide were photographed and two peritoneal thickness evaluations were performed in two different sites of each one of the five fields with the aid of a digital camera (lens of 20x) using the Zeiss Axio Vision ${ }^{\circledR}$ software version 3.0 calibrated with the digitalized image of the Neubauer chamber photographed with the same parameters adopted in microscope slides photography. The evaluation of the peritoneal thickness in the digitalized images was performed considering the mesothelium as surface limit and the first muscular cell as deep limit of the segment that included the mesothelium and the submesothelial zone in two different sites of each one of the five photographed fields in the slides. Transmission Electronic Microscopy (TEM) . For the analysis under transmission electronic microscopy, fragments of $1 \mathrm{~mm}^{3}$ were obtained and included in fixing solution composed of $2 \%$ paraformaldehyde, $2 \%$ glutaraldehyde in sodium cacodylate buffer $0.1 \mathrm{M}, \mathrm{pH}$. 7.2. The fixing procedure occurred for a period of $24 \mathrm{~h}$. After fixation, the tissue was washed three times with the same buffer for a period of $1 \mathrm{~h}$. The post-fixation procedure was performed in osmium tetroxide solution and potassium ferricyanide for $1 \mathrm{~h}$ in the absence of light. The dehydration was performed in progressive concentrations of acetone and inclusion in Spurr resin. The cuts were obtained in ultramicrotome Leica AG ${ }^{\mathrm{TM}}$ Type 705001 in sections of 70 to $90 \mathrm{~nm}$ with the use of diamond cutting blade. The sections were collected in copper web of 200 mesh and contrasted in uranile acetate and lead citrate solutions. The analyses were performed in transmission electronic microscope (Jeol JEM-1011C ${ }^{\mathrm{TM}}$ Electronic Microscopy) operated at $80 \mathrm{Kv}$ in the Electronic Microscopy Laboratory of the Department of Cellular Biology - University of Brasília by evaluating morphological alterations and the ultrastructure of the mesothelial cells. In the TEM analysis, although the mesothelial cell was the main focus, other cells found at the submesothelial zone, conjunctive tissue and muscular tissue of the PC anterolateral wall were also evaluated.

\section{Statistical analysis}

The statistical calculations were performed with the use of the Statistical Package Social for Sciences software (SPSS.13) applying the Levene Proof, Analysis of Variance and the Mann-Whitney test. Probabilities of $p<0.05$ were considered as significant.

\section{Results}

The experimental model allowed performing the study with the use of aluminum frame for PC exposition, which facilitated the opening and uniform exposition of the surgical wound. No inter-group and intra-group significant differences in relation to the weight of animals were verified, which was performed at the operation and at the re-operation days: $p>0.05$, (Table 2). In relation to weight, the sample seemed to be homogeneous, with $\mathrm{p}=0.151$ at the operation day and $\mathrm{p}=0.481$ at the re-operation day and in agreement with the Levene test for homoscedasticity.

\section{Clinical evolution}

No death was verified. Two animals presented diarrhea, one from group HS and another from group HT. One animal from group SH developed with abdominal distension and dehiscence of the surgical wound suture; however, after reestablished from anesthesia, all animals remained active until the re-operation moment.

TABLE 2 - Analysis of variance applied to weight of animals measured at the operation and at the re-operation days

\begin{tabular}{llclccc}
\hline Weights & Source & Sum of the Squares & $\mathrm{gl}$ & Quadratic average & $\mathrm{F}$ & Significance \\
\hline At the & Inter-groups & 2638.905 & 5 & 527.781 & 1.930 & 0.104 \\
operation day & Intra-groups & 14764.023 & 54 & 273.408 & & \\
& Total & 17402.928 & 59 & & & \\
\hline At the & Inter-groups & 1748.771 & 5 & 349.754 & 1.239 & 0.304 \\
reoperation day & Intra-groups & 15238.358 & 54 & 282.192 & & \\
& Total & 16987.129 & 59 & & & \\
\hline
\end{tabular}




\section{Light microscopy}

The examination of the microscope slides showed normal mesothelium, edema, vascular congestion, erythrocyte extravasation, mesothelium destruction, focal necrosis and thickening of the peritoneum, mesothelium and submesothelial zone (Figure 2).

\section{Edema}

Slight-degree edema was found in $80 \%$ of samples of animals from group HS, 60\% from group HT, 20\% from group BT, 50\% from group TZ, 40\% from group SH and $30 \%$ from group CG. Moderate-degree edema was found in $10 \%$ of samples of animals from group HS and in $20 \%$ from group TZ. No edema that could be classified as intense was found. A significant difference $(\mathrm{P}=0.028)$ was observed in the edema incidence when samples of animals from group HS were compared to those from group CG (Table 3).

\section{Vascular congestion}

Slight-degree vascular congestion was found in $10 \%$ of samples of animals from group HS, $20 \%$ from group HT, $10 \%$ from group BT, and 20\% from group TZ. Moderate-degree vascular congestion was found in $10 \%$ of samples of animals from groups HS and HT. No intense vascular congestion was verified. No significant difference
( $\mathrm{P}<0.05)$ was observed in the vascular congestion incidence when samples of animals from group HS were compared to those from groups CG and SH (Table 3).

\section{Erythrocyte extravasation}

Slight-degree erythrocyte extravasation was found in $60 \%$ of samples of animals from group HS and in $10 \%$ from group HT. No moderate or intense erythrocyte extravasation was verified. No significant difference ( $\mathrm{P}$ $<0.05)$ was observed in the erythrocyte extravasation incidence when samples of animals from group HS were compared to those from groups CG and SH (Table 3).

\section{Mesothelium destruction}

Slight-degree mesothelium destruction was found in $40 \%$ of samples of animals from group HS, $60 \%$ from group HT, 30\% from group BT, 60\% from group TZ, 40\% from group SH and 20\% from group CG. Moderate-degree mesothelium destruction was found in $60 \%$ of samples of animals from group HS, 40\% from group HT, 70\% from group BT, 40\% from group TZ, 60\% from group $\mathrm{SH}$ and $70 \%$ from group CG. No intense mesothelium destruction was found. No significant difference $(\mathrm{P}<0.05)$ was observed in the mesothelium destruction incidence when samples of animals from group HS were compared to those from groups CG and SH (Table 3).

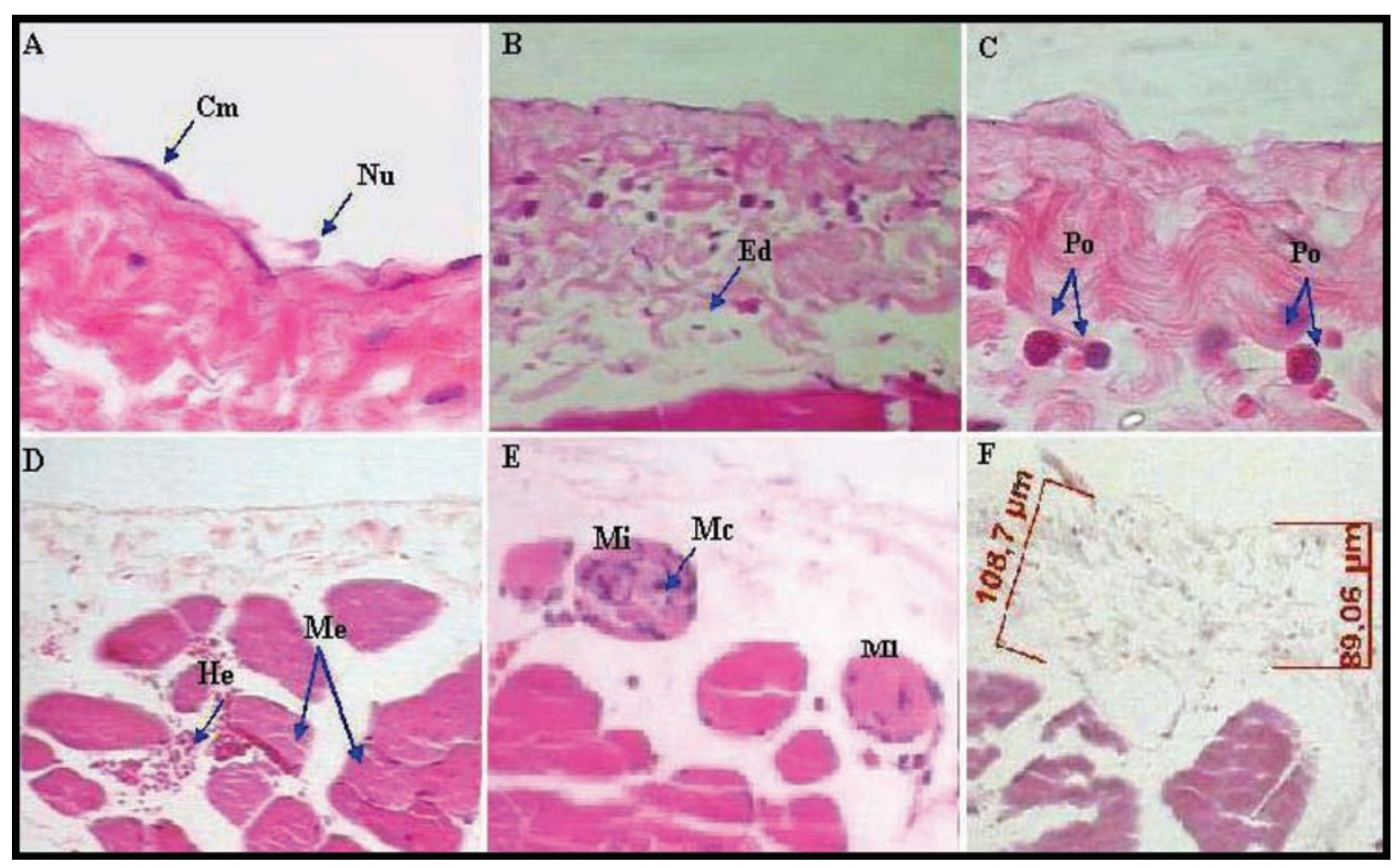

FIGURE 2 - Photomicrography in LM: Preserved mesothelium, 100x (A), edema 40x (B), absence of mesothelium, 100x (C), erythrocyte extravasation, 20x (D), necrosis, ml 40x (E), and increase on the peritoneum thickness, 20x (F) (HE stain). Cm: mesothelial cell, Nu: nucleus, Ed: edema, Po: polymorphonuclear, He: erythrocytes, Mi: myocytes, Mc: macrophages; Me: skeletal muscle 
TABLE 3 - Percentage and counting of histopathologic alterations distributed per group of animals and statistical significance between groups HS (heat shock), HT (high temperature), BT (body temperature) and TZ (temperature zero degree) and groups SH (sham) and CG (control group)

\begin{tabular}{|c|c|c|c|c|c|c|c|}
\hline & & & Edema & $\begin{array}{l}\text { Vascular } \\
\text { congestion }\end{array}$ & $\begin{array}{l}\text { Erythrocyte } \\
\text { extravasation }\end{array}$ & $\begin{array}{l}\text { Mesothelium } \\
\text { destruction }\end{array}$ & Necrosis \\
\hline \multirow[t]{6}{*}{ Groups } & HS & $\begin{array}{l}\text { Counting } \\
\text { \% in group } \\
\text { Sig. SH } \\
\text { Sig. CG }\end{array}$ & $\begin{array}{l}8 \\
80 \% \\
0.075 \\
* 0.028\end{array}$ & $\begin{array}{l}2 \\
20 \% \\
0.147 \\
0.147\end{array}$ & $\begin{array}{l}0 \\
0 \% \\
0.317 \\
1\end{array}$ & $\begin{array}{l}10 \\
100 \% \\
1 \\
0.786\end{array}$ & $\begin{array}{l}3 \\
30 \% \\
0.067 \\
0.067\end{array}$ \\
\hline & HT & $\begin{array}{l}\text { Counting } \\
\% \text { in group } \\
\text { Sig. SH } \\
\text { Sig. CG }\end{array}$ & $\begin{array}{l}6 \\
60 \% \\
0.386 \\
0.189\end{array}$ & $\begin{array}{l}3 \\
30 \% \\
0.68 \\
0.68\end{array}$ & $\begin{array}{l}6 \\
60 \% \\
* 0.022 \\
* 0.004\end{array}$ & $\begin{array}{l}10 \\
100 \% \\
0.383 \\
0.302\end{array}$ & $\begin{array}{l}2 \\
20 \% \\
0.146 \\
0.146\end{array}$ \\
\hline & BT & $\begin{array}{l}\text { Counting } \\
\text { \% in group } \\
\text { Sig. SH } \\
\text { Sig. CG }\end{array}$ & $\begin{array}{l}3 \\
30 \% \\
0.786 \\
0.888\end{array}$ & $\begin{array}{l}1 \\
10 \% \\
0.317 \\
0.317\end{array}$ & $\begin{array}{l}0 \\
0 \% \\
0.317 \\
1\end{array}$ & $\begin{array}{l}10 \\
100 \% \\
0.648 \\
0.888\end{array}$ & $\begin{array}{l}1 \\
10 \% \\
0.317 \\
0.317\end{array}$ \\
\hline & $\mathrm{TZ}$ & $\begin{array}{l}\text { Counting } \\
\% \text { in group } \\
\text { Sig. SH } \\
\text { Sig. CG }\end{array}$ & $\begin{array}{l}7 \\
70 \% \\
0.112 \\
0.054\end{array}$ & $\begin{array}{l} \\
20 \% \\
0.146 \\
0.146\end{array}$ & $\begin{array}{l}0 \\
0 \% \\
0.317 \\
1\end{array}$ & $\begin{array}{l}10 \\
100 \% \\
0.383 \\
0.302\end{array}$ & $\begin{array}{l}0 \\
0 \% \\
1 \\
1\end{array}$ \\
\hline & $\mathrm{SH}$ & $\begin{array}{l}\text { Counting } \\
\% \text { in group }\end{array}$ & $\begin{array}{l}4 \\
40 \%\end{array}$ & $\begin{array}{l}0 \\
0 \%\end{array}$ & $\begin{array}{l}1 \\
10 \%\end{array}$ & $\begin{array}{l}10 \\
100 \%\end{array}$ & $\begin{array}{l}0 \\
0 \%\end{array}$ \\
\hline & CG & $\begin{array}{l}\text { Co unting } \\
\% \text { in group }\end{array}$ & $\begin{array}{l}3 \\
30 \%\end{array}$ & $\begin{array}{l}0 \\
0 \%\end{array}$ & $\begin{array}{l}0 \\
0 \%\end{array}$ & $\begin{array}{l}9 \\
90 \%\end{array}$ & $\begin{array}{l}0 \\
0 \%\end{array}$ \\
\hline
\end{tabular}

* Statistically significant

\section{Focal necrosis}

Slight-degree focal necrosis was found in 30\% of samples of animals from group HS, 20\% from group HT and $10 \%$ from group BT. No moderate or intense focal necrosis was found. No significant difference $(\mathrm{P}<0.05)$ was observed in the focal necrosis incidence when samples of animals from group HS were compared to those from groups CG and SH (Table 3).

\section{Peritoneal thickness}

The peritoneal thickness ranged from $14.01 \mu \mathrm{m}$ to $93.37 \mu \mathrm{m}$, but no significant difference in the peritoneal thickness was found in inter-group and intra-group samples according to the analysis of variance $p=0.146$ (Table 4). The means of the peritoneal thickness measurements of animals from each group grouped as quartiles were similar for groups $\mathrm{HE}$ and $\mathrm{CG}$, with higher incidence in the $3^{\text {rd }}$ quartile, while for group $\mathrm{SH}$, the highest concentration occurred in the $1^{\text {st }}$ quartile. A discrepant value for group BT in relation to the other groups was found ${ }^{93,37}$, concerning the animal number 31, which was excluded from the nalysis (Figure 3).

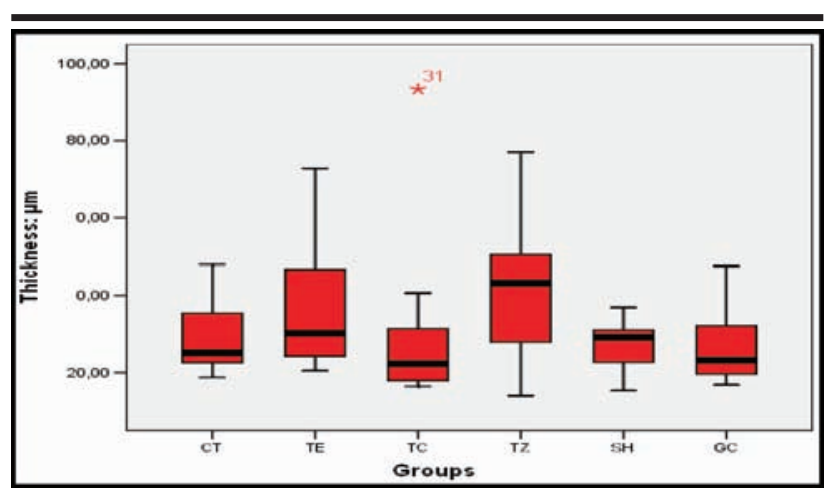

FIGURE 3 - Groups $\mathrm{x}$ thickness. Measurements of peritoneal thickness, mesothelium and submesothelial zone of samples from groups HS (heat shock), HT (high temperature), BT (body temperature), TZ (temperature zero degree), SH (sham) and CG (control group)

TABLE4-Analysis of variance for the peritoneal thicknessin $\mu$ mmeasured in the digitalizedimages fromhistological sections

\begin{tabular}{llllll}
\hline & Sum of the squares & gl & Quadratic average & F & Sig. \\
\hline Intergroups & 1961.490 & 5 & 392.298 & 1.610 & 0.173 \\
Intragroups & 13155.475 & 54 & 243.620 & & \\
Total & 15116.965 & 59 & & & \\
\hline
\end{tabular}




\section{Electronic microscopy}

The analysis was limited to the morphology of mesothelial cells found in the conjunctive tissue, although samples presented muscular tissue, collagen, capillaries, erythrocytes and inflammatory cells. Specimens collected from groups SH and CG presented mesothelial cells that adhered more easily to the subjacent conjunctive tissue than those from groups BT and HT, where mesothelial cells were free or partially detached from the conjunctive tissue (Figure 4). On the other hand, cells with morphological alterations such as membrane rupture with cytoplasm extravasation and abundant vacuoles, erythrocytes outside capillaries, were found in samples from groups HS, HT and $\mathrm{TZ}$, but these alterations were more frequent in groups HS and HT.

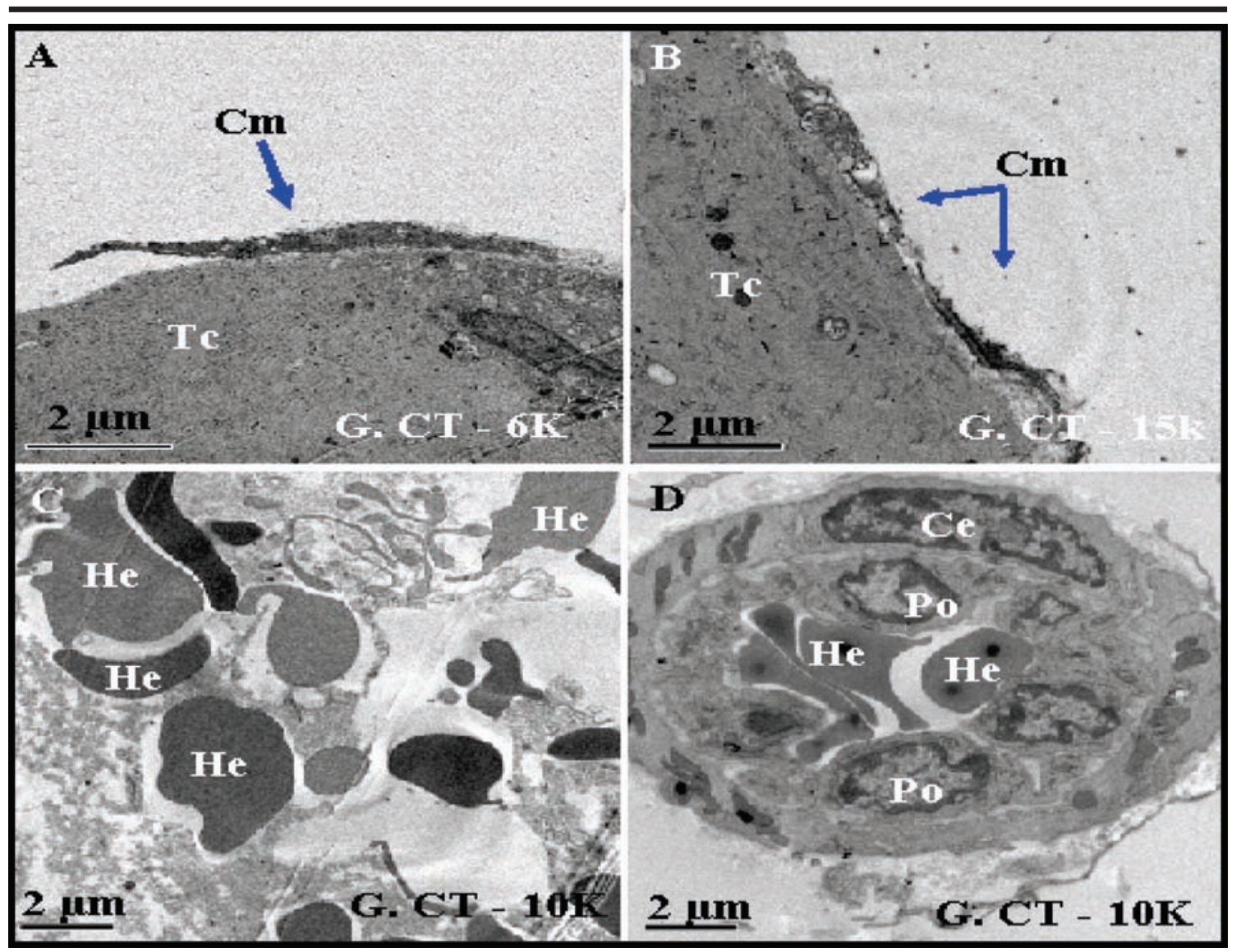

FIGURE 4 - Photomicrography: Mesothelial cell partially detached from the conjunctive tissue, (A). Mesothelial cell with ruptures on the cell membrane and vacuolization, (B). Erythrocyte extravasation, (C) Vascular congestion, (D). Cm, mesothelial cell; Tc, conjunctive tissue; Ce, endothelial cell and Po, polymorphonuclear

\section{Discussion}

The efficiency obtained in the use of the saline solution in PL associated or not to other substances to reduce the peritonitis contamination level is frequently reported; however, reports on the effects of the heat shock that the temperature of these solutions may produce on the peritoneum and even on the muscular fibers of the abdominal wall are scarce. The heat shock caused by PL with heated saline solution followed by another PL with cooled solution could produce damages to microorganisms with no death or irreversible injuries to host tissue similarly to what occurs in pasteurization, what makes HS an additional resource in the peritonitis treatment. Thus, this study evaluated histopathologic alterations of peritoneum exposed to heat shock so that a subsequent study would evaluate its effect on the peritonitis treatment. In a pilot study, $60 \%$ of rats exposed to peritoneal lavage with saline solution at temperature of $60^{\circ} \mathrm{C}$ died in the first 24 hours and no deaths were observed when irrigations were conducted with solution at temperature lower than or equal to $50^{\circ} \mathrm{C}$. This result is similar to that obtained by Silva et al. ${ }^{19}$, who found mortality rate of $66 \%$ when saline solution at $60^{\circ} \mathrm{C}$ was used for PL during $1 \mathrm{~min}$ and no death among animals was observed when the solution temperature was $45^{\circ} \mathrm{C}$. Therefore, in order to avoid high mortality rates and to reproduce the process, saline solution at maximum temperature of $50^{\circ} \mathrm{C}$ and minimum between $0^{\circ} \mathrm{C}$ and $2^{\circ} \mathrm{C}$ 
was used, unlike methods used by authors who do not support the immediate cooling through irrigation of the PC with saline solution at temperature between $0^{\circ} \mathrm{C}$ and $2^{\circ} \mathrm{C}$ and consequent heat shock ${ }^{16,18,19}$. During the surgical procedure, the PC exposition through aluminum frame promoted the opening and immobilization of the surgical wound, thus allowing safe peritoneal irrigation and avoiding different positions in relation to operated animals. This technique avoided overflow of saline solution like when wound edges are fixed with homeostatic nippers and presented by the assistant that hardly ever keep stable while the surgeon pours the saline solution inside the PC and especially during exposition periods, thus causing a bias that could distort results and cause complications such as tissue rupture due to excessive tension. When the PC was filled up with saline solution at temperature of $50^{\circ} \mathrm{C}$, a dilatation of the subserous vessels was observed and when the solution temperature was between $0^{\circ} \mathrm{C}$ and $2^{\circ} \mathrm{C}$, a contraction of the intestinal vessels was otherwise observed, which presented smaller caliber when compared to the macroscopic aspect of the subserous vascularization before irrigations. Similar results were reported by Silva et al. ${ }^{16}$ when an intraperitoneal infusion of $20 \mathrm{ml}$ of saline solution at $38^{\circ} \mathrm{C}$ was used. Histopathologic alterations such as edema, vascular congestion, erythrocyte extravasation, mesothelium destruction and focal necrosis of muscular cells observed at light microscopy that characterized cellular aggression occurred; however, the intensity of these alterations was not sufficient to produce death. When histopathologic alterations found for group HS were compared to those observed for group CG, significant differences in relation to variable edema and differences statistically not significant in relation to variables congestion, erythrocyte extravasation, mesothelium destruction and focal necrosis of muscular cells were found. When these histopathologic indicatives found for the other groups HT, BT and TZ were compared to those observed for groups $\mathrm{SH}$ and $\mathrm{CG}$, no significant differences were found, except for the erythrocyte extravasation incidence for group HT, which was significant in relation to SH and CG, thus justifying the necessity to control the temperature of saline solutions employed, as proposed by Silva et al. ${ }^{19}$. Mesothelium destruction occurred to $100 \%$ of samples from all groups, except for group CG, which presented $90 \%$, similarly to what was reported by Silva et al. ${ }^{19}$, it cannot be exclusively attributed to PC irrigations with saline solution, but also to the technical difficulty found in maintaining the peritoneal mesothelial cells. In general, the peritoneum is quite thin and easily detaches from the subjacent conjunctive tissue. Histopathologic alterations observed in muscular cells of the PC anterolateral wall of animals from groups HS, HT (20\%) and TZ suggestive of degeneration and necrosis such as loss of striations, cytoplasm vacuolization and shapeless aspect of the tissue, as reported by Silva et al. ${ }^{19}$ were not found in samples of animals from group CG. The thickness of the peritoneum, mesothelium and submesothelial zone may exceed $300 \mu \mathrm{m}$ after secondary peritonitis, peritoneal dialyses and in rats when the PC is exposed to biological agents ${ }^{9}$. Although in this study a physical agent has been used to stimulate the peritoneum, the heat shock, an increase on the average peritoneal thickness was also observed especially in groups HT and TZ in relation to the group CG. This increase was mainly caused by edema and was smaller than that observed when the peritoneum is exposed to biological agent that produces increases on the cellularity, as reported by Margetts et al. ${ }^{16}$, who injected intraperitoneal AdIL-70 (Adenovirus Interleukin Innocuous - control) and AdIL-1ß (Adenovirus Interleukin $ß$ ) and observed increase on the peritoneal thickness 9 . The fact that the average peritoneal thickness of group HS, $x=29.26 \mu$ m was smaller in relation to groups HT and TZ leads us to infer that the exposition of the PC to saline solution at temperature between $0^{\circ} \mathrm{C}$ and $2^{\circ} \mathrm{C}$ shortly after irrigation with saline solution at $50^{\circ} \mathrm{C}$ had no accumulative effect on the average thickness (HT+TZ), but rather, the average thickness was smaller than that verified when irrigation was conducted with saline solution at $50^{\circ} \mathrm{C}$, group $\mathrm{HT}$, or between $0^{\circ} \mathrm{C}$ and $2^{\circ} \mathrm{C}$, group $\mathrm{TZ}$. On the other hand, morphological alterations and cellular ultra-structure observed under TEM such as rupture of the cell membrane, cytoplasm extravasation, vacuolization and degeneration of cell nucleuses in samples from different groups were analyzed and based on histopathologic alterations that suggest that cellular architecture of the peritoneum was more preserved in the Control Group than in the Heat Shock Group, corroborating results obtained through light microscopy.

\section{Conclusion}

The heat shock under conditions established in the present study did not cause any death, but promoted significant peritoneal edema without altering the other histopathologic indicatives.

\section{References}

1. Price J. Surgical intervention in cases of general peritonitis from typhoid fever and acute gonococcus infection. Am Med. 1905;9:769-72.

2. Noon GP, Beall JrAC, Jordan Jr GL, Riggs Jr S, DeBakey ME. Clinical evaluation of peritoneal irrigation with antibiotic solution. Surgery. 1967;62(1):73-8.

3. Holzheimer RG, Dralle H. Paradigm change in 30 years peritonitis treatment: a review on source control. Eur J Med Res. 2001;6(4):161-8.

4. Munsom JL. Tratamento da sepse intra-abdominal. Clin Cir Am Norte. 1991;71(6):1253-63.

5. Oliveira PG de. Efeitos da peritonite por Cândida Albicans na cicatrização de anastomoses colônicas: estudo experimental em ratos [Tese]. Ribeirão Preto: FaculdadedeMedicina,UniversidadedeSãoPaulo;1995. 
6. Condon RE, Malangoni AM. Peritonite e abscessos intra-abdominais. In: Schwartz SI, Shires TG, Spencer FC, Storer EH. Princípios de cirurgia. 4ed. Rio de Janeiro: Guanabara Koogan; 1988, p.1559-60.

7. Maingot R. Acute peritonitis. In: Maingot R. Abdominal operations. 6ed. New York: Appleton-Century Croftis; 1974. p.1416-6.

8. Michailova K, Wassilev W, Wedel T. Scanning and transmission microscopic study of visceral and parietal peritoneal regions in the rat. Ann Anat. 1999; 181(3):253-60.

9. Margetts PJ, Kolb M, Yu L, Holf CM, Holmes CJ, Anthony DC, Gauldie J. Animal model: inflammatory cytokines, angiogenesis and fibrosis in the rat peritoneum. Am J Pathol. 2002;160(6):2265-94.

10. Torek FAM. The treatment of diffuse suppurative peritonitis following appendicitis. Med Rec. 1906;70(22):849-58.

11. Nyström PO, Johansson L, Skaut T, Lennquist S. Intra-operative irrigation of the peritoneal cavity with ampicillin in experimental postraumatic peritonitis. Acta Chir Scand. 1984;150(1):45-9.

12. Ayala LA. Lavado peritoneal como solución salina vs yodopovidona en peritonitis experimental. In: Patino JF. Infección quirúrgica. Bogotá: Centro Medico de los Andes; 1989. p.191-8.

13. Saha SK. Efficacy of metronidazole lavage in teatment of intraperitoneal sepsis: a prospective study. Dig Dis Sci. 1996;41(7):1313-8.

14. Aguilar-Nascimento JE, Soares TY, Silveira BRP, Silva MRN, Caporossi C. Influência da lavagem da cavidade peritoneal com glicose hipertônica a 10\% na cicatrização por segunda intenção do colo em vigência de peritonite fecal: estudo experimental em ratos. Acta Cir Bras. 1992;7(1)17-20.

15. Barekzi AN, Poelstra FGA, Rojas AI, Slunt BJ, Grainger WD. Efficacy of locally delivered polyclonal immunoglobulin against Pseudomonas aeruginosa peritonitis in murine model. Antimicrob Agents Chemother. 1999;43(7):1609-15.

16. Silva DF, Haga E, Hashimoto A, Succi GM, Mitsue A, Tsunematsu E, Magalhães HP. Análise dos efeitos da lavagem peritoneal com soro fisiológico a $0,9 \%$ a $38^{\circ} \mathrm{C}$ sobre o peritônio de ratos sadios. Rev Med. 1996;75(4):232-41.

17. Name JE. Choque térmico e osmolar nas peritonites. Rev Saúde Dist Fed. 1991;2(4):249-50.

18. Töth T, Fenyvesi A, Klemm I. The effects of local hyperthermia on the morphology of the small bowel. Acta Physiol Hung. 1992;80(1-4):293-301.

19. Silva AL, Salles PGO, Miranda ES, Biet R, Veloso SG, Carmo AAL. Efeito histológico causado na parede posterior da cavidade abdominal pela lavagem com solução salina $0,9 \%$ aquecida a diferentes temperaturas: estudo experimental em ratos. Acta Cir Bras. 2001;16(1):52-5.

20. Fonseca JML, Ribeiro SP. Efeitos protetores do choque térmico na sepse na síndrome da resposta inflamatória sistêmica. Rev HCPA. 1999;19(3):3396-406.

21. Aretxabala X, Yonemura Y, Fujimura T, Urada F, Hasegawa H, Miwa K, Miyazaki I, Hipertermia peritoneal en la prevención de recurrencia peritoneal debida a cáncer gástrico. Rev Chil Cir. 1989;41(3):262-4.

22. Debré PA O laboratóiro de Arbois. In: Debré PA. Pasteur. São Paulo: Ed. Scritta; 1995. p.257-61.

23. Brundell SM, Tucker K, Chatterton B, Hewett PJ. The effect of lavage intraabdominal cell burden. Surg Endosc. 2002;16(7):1064-7.

24. Rocha JJR, Aprilli F, Santos JCM Jr, Guimarães AS. Tratamento da peritonite generalizada grave: trabalho experimental em cobaias. Rev Col Bras Cir. 1986;13(5):218-23.

25. Nover L. 125 years of experimental heat shock research: historical roots of a discipline. Genome. 1989;31(2):668-70.

\section{Correspondence:}

João Vieira Lopes

SQN, 202 Bl C/203

70832030 Brasília - DF Brazil

Phone: (55 61)3326-5786

joaolopes@unb.br
Conflict of interest: none

Financial support: none

Received: April 09, 2007

Review: June 14, 2007

Accepted: July 16, 2007

\section{How to cite this article}

Lopes JV, Oliveira PG, Sousa JB, Báo SN, Takano GHS, Leal IIR. Histopathologic evaluation of the peritoneum exposed to heat shock: experimental study in rats. Acta Cir Bras. [serial on the Internet] 2007 Sept-Oct;22(5). Available from URL: http://www.scielo.br/acb 